\title{
The reliability of osteometric techniques for the sex determination of burned human skeletal remains
}

David Gonçalves

Research Centre for Anthropology and Health (CIAS), Universidade de Coimbra. Rua do Arco da Traição, 3000-056, Coimbra, Portugal.

Forensic Sciences Research Centre (CENCIFOR), Instituto Nacional de Medicina Legal.

Largo da Sé Nova, 3000-213, Coimbra, Portugal.

Instituto de Gestão do Património Arquitectónico e Arqueológico, I. P., Portugal. Rua da Bica do Marquês 2, 1300-087 Lisboa, Portugal.

Received 11 February 2011; accepted 29 June 2011

*Tel.: +351 963501561. E-mail address: davidmiguelgoncalves@ gmail.com 


\begin{abstract}
The influence of heat-induced shrinkage on the osteometric sexual dimorphism of human skeletons is still poorly known. In order to investigate this issue, a sample composed of 84 Portuguese individuals cremated at a modern crematorium was examined using standard measurements from the femur, the talus and the calcaneus. In addition, sex determination of the sample was attempted by using osteometric standards developed from the Coimbra collection of identified skeletons. This was carried out to assess the extent of the effect of heat-induced shrinkage on the correct classification of known-sex skeletons while using standards developed on unburned skeletons.

Results demonstrated that sexual dimorphism was still observable in the sample of calcined bones despite shrinkage. However, the application of conventional osteometric standards was unsuccessful. As expected, shrinkage caused most females to be correctly classified according to sex, but the sex allocation of males was very poor for all standard measurements.

The results were obtained on a small sample but suggest that univariate metric techniques specifically developed for calcined bones may be valuable for sex determination. This would bring new methodological possibilities for biological anthropology and would enlarge the set of techniques regarding sex determination of burned skeletal remains.
\end{abstract}

Resumo

O efeito da redução de volume térmico-induzida no dimorfismo sexual de esqueletos está parcamente documentado. De forma a investigar esta questão, algumas medidas-padrão do fémur, do astrágalo e do calcâneo foram examinadas num conjunto de 84 indivíduos Portugueses cremados em crematório moderno. A juntar a isto, a determinação sexual da amostra recorrendo aos protocolos de análise osteométricas desenvolvidos a partir da coleção de esqueletos identificados de Coimbra foi também ensaiada. O objectivo deste procedimento consistiu em avaliar o efeito da redução de volume térmico-induzida no índice de classificação correcta de esqueletos - cujo sexo é conhecido - a partir de protocolos de análise desenvolvidos em esqueletos não-queimados. 
Os resultados confirmaram a preservação de dimorfismo sexual em ossos calcinados apesar da redução de volume térmico-induzida. No entanto, a aplicação de referências osteométricas convencionais não foi bem-sucedida. Tal como esperado, a redução de volume conduziu à correcta classificação sexual da maioria das mulheres, mas a mesma operação obteve reduzido êxito no caso dos homens independentemente da medida-padrão testada.

Apesar de obtidos numa pequena amostra, os resultados sugerem que técnicas osteométricas univariadas especificamente desenvolvidas a partir de ossos calcinados podem contribuir para determinações sexuais fiáveis. A sua eventual confirmação trará novas possibilidades metodológicas ao campo da antropologia biológica e por conseguinte ampliará o conjunto de técnicas actualmente adoptadas para a determinação do sexo em restos humanos queimados. 


\section{Introduction}

The analysis of burned skeletal remains is very challenging because heat-induced changes and fragmentation severely interfere with bone examination and hamper analytical methods commonly used for biological profiling (Fairgrieve, 2008; Piontek, 1975; Thompson, 2002, 2004). Osteometric techniques are especially affected by heatinduced changes on bones, in particular by shrinkage which is caused by dehydration, loss of organic components and by recrystallization followed by fusion of hydroxyapatite crystals (Bradtmiller and Buikstra, 1984; Dokladal, 1962; Hiller et al., 2003; Holden et al., 1995; Grupe and Hummel, 1991; Stiner et al., 1995; Thompson, 2004).

The prediction of sex using osteometric techniques is affected by the differential shrinkage that bones undergo during burning events. Several authors state that percentage of shrinkage is related to the extent of the combustion, being negligible at low temperatures and occurring mainly at temperatures higher than $700^{\circ}-800^{\circ} \mathrm{C}$ (Buikstra and Swegle, 1989; Herrmann, 1977; Shipman et al., 1984; Thompson, 2004). At these temperatures, bones have experienced or are experiencing the four theoretical phases of heat-induced transformation: dehydration occurs at temperatures between $100^{\circ}$ and $600^{\circ} \mathrm{C}$; decomposition is related to removal of organic components at $300^{\circ}$ to $800^{\circ} \mathrm{C}$; inversion refers to removal of carbonates between $500^{\circ}$ and $1000^{\circ} \mathrm{C}$; and shrinkage occurs during the fusion phase at temperatures above $700^{\circ} \mathrm{C}$. These temperature intervals have been revised by Thompson (2004) after Mayne Correia (1997). Buikstra and Swegle (1989) reported less than 6\% of shrinkage at temperatures higher than $800^{\circ} \mathrm{C}$ but values as high as $30 \%$ in size reduction have been observed by Grupe and Hummel (1991). Therefore, a considerable variation in the rate of shrinkage has been detected. This may be related to factors such as type of bone or bone mineral content (Herrmann, 1977; Mayne Correia, 1997).

Despite differential shrinkage, several authors have pointed out that an osteometric approach may have some use regarding the sex determination of individuals based on burned bones (Holck, 1986; Malinowski, 1969; Piontek, 1975, 1976; Rösing, 1977) although its limited potential has been recurrently stated (Dokladal, 1962; Fairgrieve, 2008; Holck, 1986; Strzałko and Piontek, 1974). Nonetheless, the work of several researchers indicated that there is potential for the use of osteometric methods on burned skeletal remains. Gejvall (1969) worked extensively with cremated bones and 
pointed out the cranial vault thickness as a valuable sex predictor. Van Vark (1975) and Van Vark et al. (1996) also resorted to mathematical and statistical analysis using standard measurements of several human bones and achieved some success attempting sex diagnosis. Schutkowski (1983) and Schutkowski and Herrmann (1983) demonstrated that burned petrous bones maintain a reasonable degree of sexual dimorphism by using discriminant analyses. As a result of his analyses on modern human cremations, Wahl (1996) indicated the presence of sexual dimorphism in a number of measurements from the skull, the femur, the humerus and the radius (Wahl, 1996). Finally, Thompson (2002) experimentally heated sheep pelves and stated that uniform heat-induced shrinkage does not affect techniques regarding multivariate sex discriminating indices. However, the same author mentioned that differential shrinkage acting over both planes of measurement of a given index interferes with their reliability. Therefore, previous researches suggest that osteometric techniques may contribute considerably to the sex determination of burned skeletal remains despite heat-induced changes.

Although the scoring of morphological traits is not as affected by shrinkage as are standard measurements, in those cases sex determination depends heavily on the scoring of multiple traits. This is often hampered by the extreme skeletal fragmentation caused by heat (Fairgrieve, 2008; Piontek, 1975). If proven to be reliable, osteometric univariate analysis may be useful for burned remains, for which diagnostic features are frequently rare (Wahl, 2008). For unburned bones, several standard measurements allow for univariate analysis with rates of correct classification higher than 80-90\%. Therefore, it is important to determine if osteometry is still of some use for burned bones despite differential shrinkage.

This research intends to assess whether the possible differential shrinkage completely eliminates sexual dimorphism from calcined bones, thus preventing the use of univariate metric methods specific to the femur, the talus and the calcaneus. In addition, we document the effect of heat-induced shrinkage on the sex classification rates by osteometric standards conventionally applied to Portuguese populations (Silva, 1995; Wasterlain and Cunha, 2000).

\section{Materials and Methods}


Permission was obtained from municipal authorities to carry out measurements of bones after cremation in a modern crematorium. A sample of 84 cremated Portuguese adult skeletons aged between 41 and 99 years was examined in order to assess the reliability of selected femoral, talar and calcaneal standard measurements for sex determination. The sample included 38 females and 46 males. Due to the nature of the sample, the average age of the individuals was extremely high (73.6 years). Although the sample was relatively large, sub-samples for each standard measurement were less numerous due to poor fire-related preservation. Figure 1 illustrates the standard measurements used for this research. These are: the vertical and transverse diameters of the femoral head, and the maximum length of the talus and the calcaneus (Martin and Saller, 1957). All these measurements allowed for rates of correct sex classification higher than $80 \%$ in previous studies (Cardoso, 2000; Silva, 1995; Wasterlain and Cunha, 2000). The standard measurements were selected due to their reliability regarding sex determination (Cardoso, 2000; Silva, 1995; Steele, 1976; Wasterlain and Cunha, 2000), their small size and to their trabecular structure which both maximise chances of preservation.

Pre-cremation measurements were not taken. Nonetheless, differential shrinkage between individuals was assumed to be present based on previous research results. According to those results, differential shrinkage has been attributable to the different combustion conditions, to which different bones have been submitted to (Buikstra and Swegle, 1989; Shipman et al., 1984; Thompson, 2002, 2005). Only bones burned at temperatures over $800^{\circ} \mathrm{C}$ were measured. The duration of cremation was 60 to 180 minutes depending on the case. The difference in the duration of combustion was mainly due to differential pyrolysis of the soft tissues. In all cases, cremation occurred until complete removal of the soft tissues and bone tissue calcination leading to a typical white colour. Measurements were carried out using a digital caliper $(0.01 \mathrm{~mm})$. Each bone was measured three times and the median value was used. Left-sided bones were used for the measurements. Right-sided bones were used when the left ones were absent. However, bilateral asymmetry was not calculated for each standard measurement because poor preservation seldom allowed for the measuring of bones from both sides.

Intra-observer error was assessed by calculating the absolute and relative technical error of measurement and the coefficient of reliability. Two measurements were carried 
out, usually with an interval of only a few minutes between them due to time constraints.

Sexual differences for each standard measurement were calculated using an independent-samples t-test. Sex determination was attempted by using cut-off points developed from Portuguese non-burned skeletons of the Collection of Identified Skeletons housed at the University of Coimbra. These standards are conventionally adopted for Portuguese populations. Bones with measurements larger than the cut-off point were allocated to males and measurements smaller than the cut-off point were allocated to females. The statistical analysis was carried out using the SPSS software, version 14.0 (SPSS Inc., Chicago IL).

\section{INSERT Fig. 1 ABOUT HERE}

\section{Results}

The results for intra-observer variation are presented in Table 1 and demonstrated good repeatability. The descriptive statistics for each standard measurement are presented in Table 2. The results of the t-test for independent-samples showed statistically significant differences between female and male mean dimensions (Table 3). All standard measurements presented statistically significant mean differences at the level $\mathrm{p}<0.01$ with a large size effect. Males consistently presented larger measurements than females. Results demonstrated that calcined bones maintained sexual differences in size after cremation.

The results for correct sex determination using the osteometric standards developed for non-burned skeletons are presented in Table 4. The percentage of correct classification was very different between females and males. Most females were correctly classified while most males were incorrectly classified.

\section{INSERT Tables 1-4 ABOUT HERE}

\section{Discussion}


Statistically significant differences between female and male mean sizes in burned bones were found for femoral and tarsal standard measurements and could therefore allow for successful sex determination. In these cases, possible differential shrinkage affecting the bones did not eliminate sexual dimorphism. This conclusion refers to calcined bones, which have experienced the dehydration, decomposition, inversion and fusion phases (Mayne Correia, 1997; Thompson, 2004). However, this outcome was obtained on a small sample and further research on a larger sample is required to confirm the current results.

Our results are in compliance with previous research, which have found sexual dimorphism in the size of burned bones (Gejvall, 1969; Schutkowski, 1983; Schutkowski and Herrmann, 1983; Van Vark, 1975; Van Vark et al., 1996; Wahl, 1996).

Standardised osteometric techniques developed using bones from the Coimbra Collection of Identified Skeletons did not successfully determine sex for most of the individuals in the studied sample. The Coimbra standards were developed based on individuals who lived in the $19^{\text {th }}$ century and the first half of the $20^{\text {th }}$ century. A positive secular trend of $89.3 \mathrm{~mm}$ was detected for the stature of the Portuguese male population between 1904 and 2000 (Padez, 2003, 2007). No data for Portuguese females are available. However, these have probably also experienced a positive trend, although their increase in height may not have been as substantial as it was for males. Such sexual dimorphism in secular trend was detected in previous studies (Cole, 2000; Kuh et al., 1991). Nonetheless, and given this increase, heat-induced shrinkage could hypothetically act as a correction factor in order to adapt the Coimbra standards to the analysis of burned bones. In other words, because our current cut-off points were calculated based on a population, which has been most probably smaller in size than the present one, bone shrinkage could eventually lead those cut-off points to be somewhat adapted to the latter. However, our results demonstrated that this was not so. Although, all females were attributed to the correct sex, the same did not occur for males. This was an expected outcome of heat-related bone shrinkage (Bradtmiller and Buikstra, 1984; Grupe and Hummel, 1991; Hiller et al., 2003; Holden et al., 1995; Stiner et al., 1995; Thompson, 2004). Although the effect of shrinkage led the dimensions of female bones to keep a smaller size than the cut-off point, it led the bones of several males to move below that very same cut-off point. Only the maximum length of the calcaneus with 
$69.6 \%(n=23)$ allowed us to obtain a score better than chance on male sex determination.

Along with sex, it would be worthwhile to include age as a factor in order to check whether accuracy in sex determination varies according to age groups. Along with the abovementioned secular trend detected by Padez (2003, 2007), age-related differences in the content of bone minerals (Hiller et al., 2003; Ravaglioli et al., 1996) may be responsible for age variation in heat-induced shrinkage. For these reasons, it would be important to establish whether age and sex together are better correlated with bone measurements than sex alone. This was not carried out because of our very aged and limited sample, which did not allow for an age group analysis.

The results support the development of new univariate osteometric standards specific to the sex determination of calcined bones. Such an achievement would have important implications for both archaeological and forensic sciences. However, the application of such standards may be problematic because the identification of calcined bones is not straightforward. Although macroscopic inspection of bones may be sufficient to identify calcined bones through colour, fractures and warping, it is also prone to error. This is mostly because of taphonomic processes that can mimic those heat-induced changes. One solution it is to rely on techniques such as X-ray Diffraction (XRD) or Fourier Transform Infrared Spectroscopy (FTIR). These techniques have the potential to identify burned bones and to grossly estimate the time and temperature of combustion to which the bones were exposed (Piga et al., 2009; Thompson et al., 2009). If we manage to determine calcination of bone with certainty, then the application of osteometric techniques specific to burned skeletal remains may soon become reliable.

Although the preservation of osteometric features may be uncommon for burned archaeological materials, the same could be stated for morphological features (Fairgrieve, 2008; Piontek, 1975). However, univariate osteometric techniques do not require the multivariate approach that is mandatory for the scoring of morphological features. Therefore, it would improve chances of achieving sex determination of unidentified individuals by enlarging the set of methods suitable for the analysis of burned bones.

\section{Acknowledgements}


The author would like to thank the Câmara Municipal do Porto (Portugal) and their staff from the municipal cemeteries, Cidália Duarte, Hugo Cardoso, Eugénia Cunha and Tim Thompson for precious scientific and logistic support. In addition, our gratitude is extended to Holger Schutkowski, Hugo Oliveira, Vera Aldeias, Leigh Oldershaw, Catarina Ginja and Ana Elisabete Pires who helped assemble some of the bibliography. A special thank you is also in order to the reviewers and the editor for their helpful comments and suggestions. This research was funded by the Fundação para a Ciência e Tecnologia (SFRH/BD/40549/2007).

\section{References}

Bradtmiller, B., Buikstra, J.E., 1984. Effects of burning on human bone microstructure: a preliminary study. J. Forensic Sci. 29, 535-540.

Buikstra, J., Swegle, M., 1989. Bone modification due to burning: experimental evidence. In: Bonnichsen, R., Sorg, M.H. (Eds.), Bone Modification. Center for the Study of the First Americans, Orono, M.E., pp. 247-258.

Cardoso, H.F.V., 2000. Dimorfismo sexual na estatura, dimensões e proporções dos ossos longos dos membros: o caso de uma amostra portuguesa dos séculos XIX-XX, Departamento de Antropologia. Universidade de Coimbra, Coimbra.

Cole, T.J., 2000. Secular Trends in Growth. Proceedings of the Nutrition Society 59, 317-324.

Dokladal, M., 1962. Uber die Moglichkeiten der Identifikation von Knochen aus Leichenbranden. Mitteilungen der Sektion Anthropoloqie 6, 15.

Fairgrieve, S., 2008. Forensic Cremation: Recovery and Analysis. CRC Press, Boca Raton, Florida.

Gejvall, N.-G., 1969. Cremations. In: Brothwell, D., Higgs, E., Clark, G. (Eds.), Science in Archaeology. Thames and Hudson, London, pp. 468-479.

Grupe, G., Hummel, S., 1991. Trace element studies on experimentally cremated bone. I. Alteration of the chemical composition at high temperatures. J. Archaeol. Sci. 18, 177-186.

Herrmann, B., 1977. On histological investigations of cremated human remains. J. Hum. Evol. 6, 101-102. 
Hiller, J.C., Thompson, T.J.U., Evison, M.P., Chamberlain, A.T., Wess, T.J., 2003.

Bone mineral change during experimental heating: an X-ray scattering investigation. Biomaterials 24, 5091-5097.

Holck, P., 1986. Cremated Bones: A medical-anthropological study of an archaeological material on cremation burials, Antropologiske Skrifter. Anatomisk Institutt Universitetet, Oslo.

Holden, J.L., Phakey, P.P., Clement, J.G., 1995. Scanning electron microscope observations of human femoral bone: a case study. Forensic Sci. Int. 74, 17-28.

Kuh, D.L., Power, C., Rodgers, B., 1991. Secular trends in social class and sex differences in adult height. Int. J. Epidemiol. 20, 1001-1009.

Malinowski, A., 1969. Synthèse des recherches polonaises effectuèes jusqu'à présent sur les os des tombes à incinération. Przegląd Antropologiczny 35, 127-147.

Martin, R., Saller, K., 1957. Lehrbuch der Anthropologie. Gustav Fisher Verlag, Stuttgart.

Mayne Correia, P., 1997. Fire modification of bone: a review of the literature. In: Haglund, W.D., Sorg, M.H. (Eds.), Forensic Taphonomy: The Postmortem Fate of Human Remains. CRC Press, New York, pp. 275-294.

Padez, C., 2003. Secular trend in stature in the Portuguese population (1904-2000). Ann. Hum. Biol. 30, 262-278.

Padez, C., 2007. Secular trend in Portugal. J. Hum. Ecol. 22, 15-22.

Piga, G., Thompson, T., Malgosa, A., Enzo, S., 2009. The potential of X-Ray diffraction in the analysis of burned remains from forensic contexts. J. Forensic Sci. $54,534-539$

Piontek, J., 1975. Polish methods and results of investigations of cremated bones from prehistoric cemeteries. Glasnik Antropološkog Društva Jugoslavije 12, 23-34.

Piontek, J., 1976. Proces kremacji i jego wpływ na morfologię kości w świetle wyników badań eksperymentalnych. Archeologia Polski 21, 247-280.

Ravaglioli, A., Krajewski, A., Celotti, G.C., Piancastelli, A., Bacchini, B., Montanari, L., Zama, G., Piombi, L., 1996. Mineral evolution of bone. Biomaterials 17, $617-$ 622.

Rösing, F.W., 1977. Methoden und Aussagemöglichkeiten der anthropologischen Leichenbrandbearbeitung. Archäologie und Naturwissenschaft 1, 53-80.

Schutkowski, H., 1983. Uber den diagnostischen Wert der Pars petrosa ossis temporalis fur die Geschlechtsbestimmung. Z. Morphol. Anthropol. 74, 129-144. 
Schutkowski, H., Herrmann, B., 1983. Zur Möglichkeit der metrischen geschlechtsdiagnose an der Pars petrosa ossis temporalis. Zeitschrift für Rechtsmedizin 90, 219-227.

Shipman, P., Foster, G., Schoeninger, M., 1984. Burnt bones and teeth: an experimental study of color, morphology, crystal structure and shrinkage. J. Archaeol. Sci. 11, 307-325.

Silva, A.M., 1995. Sex assesment using the calcaneus and talus. Antropologia Portuguesa 13, 107-119.

Steele, D.G., 1976. The estimation of sex on the basis of the talus and calcaneus. Am. J. Phys. Anthropol. 45, 581-588.

Stiner, M.C., Kuhn, S.L., Weiner, S., Bar-Yosef, O., 1995. Differential burning, recrystallization and fragmentation of archaeological bone. J. Archaeol. Sci. 22, 223237.

Strzałko, J., Piontek, J., 1974. Wpływ spalania w warunkach zbliżonych do kremacji pradziejowych na morfologię kości. Przegląd Antropologiczny 40, 315-326.

Thompson, T., 2002. The assessment of sex in cremated individuals: some cautionary notes. Canadian Society for Forensic Sciences 35, 49-56.

Thompson, T., 2004. Recent advances in the study of burned bone and their implications for forensic anthropology. Forensic Sci. Int. 146S, S203-S205.

Thompson, T.J.U., 2005. Heat-induced dimensional changes in bone and their consequences for forensic anthropology. J. Forensic Sci. 50, 185-193.

Thompson, T., Gauthier, M., Islam, M., 2009. The application of a new method of Fourier Transform Infrared Spectoscopy to the analysis of burned bone. J. Archaeol. Sci. 36, 910-914.

van Vark, G.N., 1975. The investigation of human cremated skeletal material by multivariate statistical methods II. Measures. Ossa 2, 47-68.

van Vark, G.N., Amesz-Voorhoeve, W., Cuijpers, A., 1996. Sex-diagnosis of human cremated skeletal material by means of mathematical-statistical and data-analytical methods. Homo 47, 305-338.

Wahl, J.K., 1996. Erfahrungen zur metrishen Geschlechtsdiagnose bei Leichenbränden. Homo 47, 339-359.

Wahl, J., 2008. Investigations on pre-Roman and Roman cremation remains from southwstern Germany: results, potentialities and limits. In: Schmidt, C.W., Symes, 
S.A. (Eds.), The Analysis of Burned Remains. Academic Press, London, pp. 145161.

Wasterlain, S.N., Cunha, E., 2000. Comparative performance of femur and humerus epiphysis for sex diagnosis. Biométrie Humaine et Anthropologie 18, 9-13. 


\section{Figure legend}

Fig. 1. Standard measurements from the femoral head, the talus and the calcaneus. 
Table 1. Results obtained for the Absolute Technical Error of Measurement (TEM), Relative Technical Error of Measurement (\%TEM) and the Coefficient of Reliability (R).

\begin{tabular}{lrrc} 
Standard Measurement & TEM $(\mathbf{m m})$ & \% TEM & R \\
\hline Femur Head Transverse Diameter & 0.12 & $0.78 \%$ & .99 \\
Femur Head Vertical Diameter & 0.18 & $0.84 \%$ & .99 \\
Talus Maximum Length & 0.13 & $0.91 \%$ & .99 \\
Calcaneus Maximum Length & 0.15 & $0.45 \%$ & .99 \\
\hline
\end{tabular}


Table 2. Descriptive statistics for each standard measurement (mm).

\begin{tabular}{llllr} 
Standard Measurement & \multicolumn{1}{c}{ Sex } & N & Mean & $\begin{array}{c}\text { Standard } \\
\text { Deviation }\end{array}$ \\
\hline \multirow{2}{*}{ Femur Head Transverse Diameter } & Female & 20 & 34.9 & 2.83 \\
& Male & 22 & 40.4 & 2.83 \\
\hline \multirow{2}{*}{ Femur Head Vertical Diameter } & Female & 20 & 37.5 & 2.81 \\
& Male & 30 & 42.6 & 3.12 \\
\hline \multirow{2}{*}{ Talus Maximum Length } & Female & 13 & 45.9 & 2.06 \\
& Male & 17 & 50.3 & 3.76 \\
\hline \multirow{2}{*}{ Calcaneus Maximum Length } & Female & 21 & 69.4 & 4.34 \\
& Male & 23 & 77.9 & 4.94 \\
\hline
\end{tabular}


Table 3. T-test results for each standard measurement according to mean measurements for each sex.

Standard Measurement

Femur Head Transverse Diameter

Femur Head Vertical Diameter

Talus Maximum Length

Calcaneus Maximum Length
T-test df

Sig.

(two-tailed)

$\begin{array}{llll}6.21 & 40 & .000 & 1.92 \\ 5.88 & 48 & .000 & 1.72 \\ 3.80 & 28 & .001 & 1.45 \\ 6.09 & 42 & .000 & 1.85\end{array}$


Table 4. Correct sex classification (C.C.) using standard cut-off points recommended by Wasterlain and Cunha (2000) and by Silva (1995).

\begin{tabular}{lllr} 
Standard Measurement & \multicolumn{1}{c}{ Sex } & N & C.C. $(\%)$ \\
\hline \multirow{2}{*}{ Femur Head Transverse Diameter } & Female & 20 & 100.0 \\
\hline \multirow{2}{*}{ Femur Head Vertical Diameter } & Male & 22 & 22.7 \\
\hline \multirow{2}{*}{ Talus Maximum Length } & Female & 20 & 100.0 \\
\hline & Male & 30 & 53.3 \\
Calcaneus Maximum Length & Female & 13 & 100.0 \\
\hline
\end{tabular}


Fig. 1

FEMORAL HEAD

TRANSVERSE DIAMETER
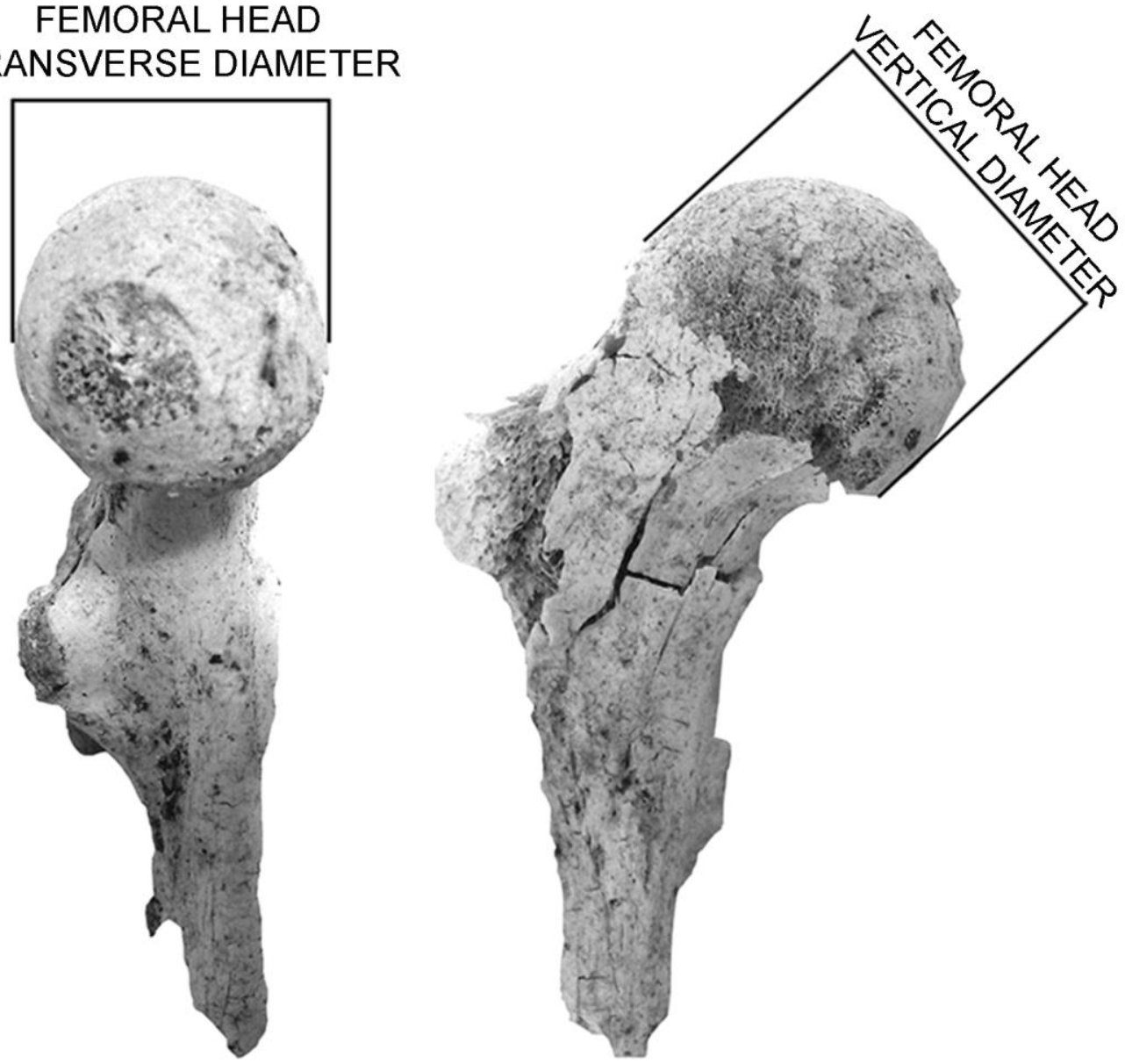

$1 \mathrm{CM}$

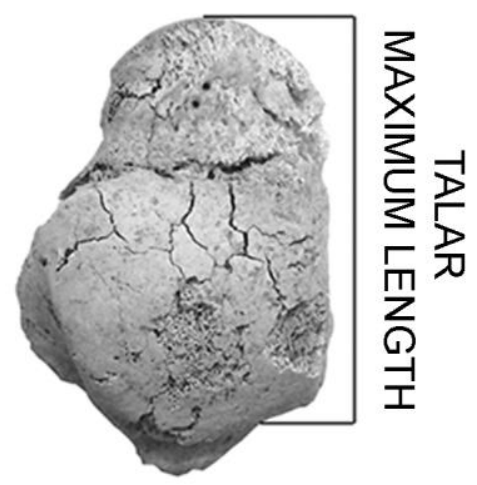

CALCANEAL MAXIMUM LENGTH

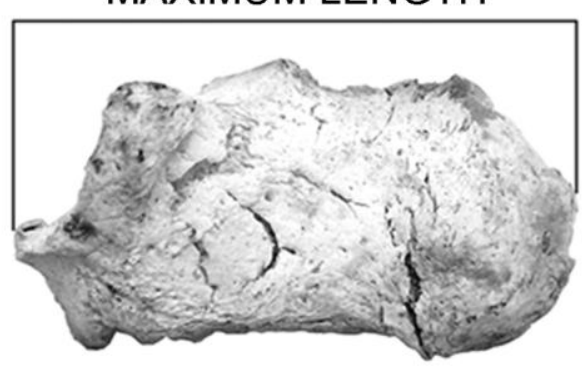

